\title{
Rancang Bangun Game Algoritma dan Struktur Data Berbasis Role Playing Game (RPG) Sebagai Media Pembelajaran Mahasiswa Teknik Informatika Universitas Muhammadiyah Sidoarjo
}

\author{
Cindy Taurusta ${ }^{* 1}$, Yulian Findawati ${ }^{2}$ \\ 1, 2 Universitas Muhammadiyah Sidoarjo \\ cindytaurusta@umsida.ac.id”
}

\begin{abstract}
Abstrak
Berdasarkan hasil survey yang dilakukan peneliti pada Mahasiswa/i Teknik Informatika semester 5 sebanyak 41.9\% dan semester 7 sebanyak 24.2\%, diperoleh hasil bahwa dari beberapa pelajaran pemrograman dasar di Jurusan Teknik Informatika, mata kuliah Algortima dan Struktur Data yang memiliki presentasi tingkat kepahaman paling rendah, yaitu $11.5 \%$ dan tingkat kesukaan/minat hanya 8.2\%. Maka dari itu peneliti membuat Rancang Bangun Game Algoritma dan Struktur Data Berbasis Role Playing Game (RPG) Sebagai Media Pembelajaran Mahasiswa Teknik Informatika Universitas Muhammadiyah Sidoarjo. mayoritas mahasiswa lebih suka bermain game sambil mengungkapkan misi yaitu sebesar 85,7\%. Dan didapat bahwa sebesar 61,9\% koresponden mengatakan bahwa game algoritma dan struktur data "Fun with ALGOS" ini sudah dapat dikatakan sangat efektif, bagus, dan menyenangkan. Sedangkan hasil apakah game ini perlu diterapkan dalam metode pengajaran algoritma dan struktur data, didapat sebesar 66,7\% mahasiswa mendukung metode ini diterapkan di seluruh Universitas. Sedangkan dari sisi Ahli Materi, sebesar 100\% mengatakan bahwa perlu ada metode pengajaran baru. Dan ketika peneliti menanyakan apakah metode pembelajaran baru itu berupa game, maka kedua ahli meteri tersebut juga seluruhnya yaitu $100 \%$ mengatakan setuju, karena memberikan warna baru dalam dunia pengajaran. Namun untuk materinya sendiri masih kurang sesuai penyampaian dalam setiap misinya, maka perlu ditingkatkan kepahaman materi dengan misi yang harus diselesaikan pemain. Dari segi ahli media sendiri mengatakan bahwa sebesar 100\% mengatakan bahwa game ini menarik untuk dimainkan begitu pun dari segi storyboard. Namun dari segi grafisnya seluruh ahli media yaitu 100\% mengatakan cukup menarik dan dari segi karakternya masih kurang dan monoton. Sedangkan dari segi ketertarikan seluruh aspek koresponden mulai dari mahasiswa, ahli materi, dan ahli media terdapat rata-rata 3.67 (sangat baik) yang membuktikan bahwa game ini sudah membuat pemainnya tertarik untuk memainkan. Dari segi pemahamannya bernilai 4 (sangat baik) dimana dari hasil kuesioner juga membuktikan bahwa dengan memainkan game ini mereka tidak hanya mengingat kembali namun juga semakin paham dengan setiap materi yang diajarkan pada mata kuliah algoritma dan struktur data. Dan dari segi Kesesuaian materi dengan misinya memperoleh nilai 3.33 (baik) karena banyak yang berpendapat kurang penjelasan lebih dalam lagi terkait misinya.
\end{abstract}

Kata kunci: Game Edukasi, Mahasiswa IT, Role Playing Game, Algoritma, dan Struktur Data

\begin{abstract}
Based on the results of a survey conducted by researchers on Students/i Information Engineering in fifth semester as much as $41.9 \%$ and seventh semesters as much as $24.2 \%$, obtained the result that from some basic programming lessons in the Department of Informatics, Algorithm and Data Structures that have the lowest level of understanding le $11.5 \%$ and interest rate only $8.2 \%$. Therefore, the researcher made the Design of Game Algorithm and Data Structure Based on Role Playing Game (RPG) as Student Learning Media of Informatics Engineering Muhammadiyah University of Sidoarjo. The majority of students prefer to play games while expressing the mission of $85.7 \%$. And it was found that $61.9 \%$ of correspondents said that the game Algorithm and Data Structuring "Fun with ALGOS" this can be said to be very effective, good, and fun. While the results of whether this game needs to be applied in teaching methods Algorithms and Data Structures, obtained by $66.7 \%$ of students support this method applied
\end{abstract}

Taurusta, C. (2017). Rancang Bangun Game Algoritma dan Struktur Data Berbasis Role Playing Game (RPG) Sebagai Media Pembelajaran Mahasiswa Teknik Informatika Universitas Muhammadiyah Sidoarjo. KINETIK, 2(3). doi:http://dx.doi.org/10.22219/kinetik.v2i3.167 Makalah dikirim 30 Juni 2017; Revisi 30 Juli 2017; Diterima 1 Agustus 2017 
throughout the University. While from the Material Expert, 100\% said that there should be a new teaching method. And when the researcher asks whether the new learning method is a game, then the two experts are also the whole 100\% said agree, because it gives a new color in the world of teaching. But for the material itself is still less appropriate delivery in each mission, it is necessary to improve the understanding of the material with the mission that must be completed players. In terms of media experts themselves say that as much as $100 \%$ said that this game is interesting to play so in terms of storyboard it. But in terms of graphic all the media experts are $100 \%$ said quite interesting and in terms of character is still less and monotonous. While in terms of interest all aspects of correspondent ranging from students, material experts, and media experts there is an average of 3.67 (very good) that proves that this game has made players interested to play. In terms of understanding is worth 4 (very good) where the results of the questionnaire also prove that by playing this game they not only remember back but also more familiar with any material taught in the course Algorithm and Data Structure. And in terms of material compatibility with mission it scores 3.33 (good) because many argue that there is less explanation more deeply related to its mission.

Keywords: Educational Game, IT Student, Role Playing Game, Algorithm, and Data Structure

\section{Pendahuluan}

Digitalisasi adalah suatu proses pengalihan bentuk bahan pustaka tertulis (hardcopy) menuju ke dalam bentuk digital (softcopy) [1]. Dengan melakukan Digitalisasi data dan informasi, maka data serta informasi tersebut tidak hanya terselamatkan, namun juga dapat disebar kemudian diakses oleh siapa saja, dimana saja, dan kapan saja. Digitalisasi dapat berupa sebuah sistem informasi berbasis web maupun aplikasi, dimana keduanya dapat dijalankan di berbagai media seperti Personal Computer (PC), handphone, tablet, dan media informasi lainnya. Digitalisasi ini umumnya dapat dilakukan oleh orang yang menguasai teknologi informasi atau lebih dikenal dengan Teknik Informatika. Kebutuhan akan lulusan Teknik Informatika yang berkompeten terutama dalam pemrograman semakin bertambah namun tidak diimbangi dengan kompetensi mahasiswa itu sendiri dalam penguasaan pemrograman. Masih banyak lulusan Informatika yang tidak bekerja dibidangnya bahkan sama sekali tidak menguasai pemrograman. Pemrograman dalam kurikulum Strata-1 (S1) Teknik Informatika Universitas Muhammadiyah Sidoarjo yaitu mulai dari algoritma pemrograman yang didapat di semester 1, kemudian algoritma dan struktur data di semester 3, dan Pemrograman Berbasis Web serta Pemrograman Berbasis Objek di semester 5 . Peneliti mencoba menelusuri penyebab kurang menguasai dan kurangnya minat mahasiswa Informatika terhadap pemrograman. Proses pembelajaran mengandung lima komponen komunikasi, guru atau dosen (komunikator), bahan pembelajaran, media pembelajaran, mahasiswa (komunikan), dan tujuan pembelajaran [2]. Media pembelajaran yang inovatif dapat dibuat dengan memanfaatkan teknologi informasi dan komunikasi. Dengan adanya bantuan dari komputer dan teknologi informasi, maka kualitas pendidikan untuk para mahasiswa dapat meningkat dan mempermudah mahasiswa dalam menerima pelajaran [3]. Media edukasi atau pembelajaran yang inovatif dapat berupa multimedia pembelajaran yang interaktif. Modelmodel multimedia pembelajaran tersebut [4] diantaranya adalah model tutorial, model Drill and Practice, model simulasi, model game, dan model hybird. Dalam hal ini, peneliti lebih memilih metode game. Pada umumnya game digolongkan menjadi beberapa genre [5], diantaranya RPG (Role Playing Game), Adventure game, RTS (Real Time Strategy), FTPS, platform games, shooter games, sport games, racing classic games, fighting games [6]. Dari beberapa genre game tersebut peneliti memilih genre RPG yang dipadukan dengan pendidikan.

Game pendidikan mempunyai potensi yang sangat besar dalam membangun motivasi pada proses pembelajaran. Pada penerapan metode konvensional untuk menciptakan motivasi belajar sebesar motivasi dalam game pendidikan dibutuhkan seorang guru/instruktur yang cakap dan piawai dalam pengelolahan proses pembelajaran. Di samping pembangkitan motivasi, game pendidikan juga mempunyai beberapa aspek yang lebih unggul dibandingkan metode pembelajaran e-learning [7].

Dari uraian tersebut maka terciptalah sebuah ide untuk membangun sebuah media pembelajaran baru dengan memanfaatkan teknologi komputer yang diharapkan mampu mengatasi masalah yang ada, yakni membuat suatu rancang bangun game algoritma dan struktur data berbasis role playing game (RPG) Sebagai Media Pembelajaran Mahasiswa Teknik

KINETIK Vol. 2, No. 3, Agustus 2017: 175-188 
Informatika Universitas Muhammadiyah Sidoarjo. Orisinalitas game pembelajaran algoritma dan struktur data pada penelitian ini murni berdasarkan pengamatan dan analisa peneliti yang telah membuat kuesioner untuk mahasiswa Teknik Informatika Universitas Muhammadiyah Sidoarjo dengan pertimbangan fasilitas yang tersedia di Fakultas dan dukungan dari Pejabat Tinggi di Fakultas Teknik khususnya Teknik Informatika. Hasil yang didapatkan akan diseminarkan dan di publikasikan pada jurnal ilmiah. Selanjutnya game edukasi yang berhasil dibuat dimanfaatkan sebagai salah satu metode baru dalam pengajaran di Teknik Informatika Universitas Muhammadiyah Sidoarjo maupun institusi lain yang membutuhkan.

Dari hasil pengujian game algoritma dan struktur data berbasis role playing game (RPG) sebagai media pembelajaran mahasiswa Teknik Informatika Universitas Muhammadiyah Sidoarjo, mayoritas mahasiswa lebih suka bermain game sambil mengungkapkan misi, yaitu sebesar $85,7 \%$. Dan didapat bahwa sebesar 61,9\% koresponden mengatakan bahwa game algoritma dan struktur data "Fun with ALGOS" ini sudah dapat dikatakan sangat efektif, bagus, dan menyenangkan. Sedangkan hasil apakah game ini perlu diterapkan dalam metode pengajaran algoritma dan struktur data, didapat sebesar $66,7 \%$ mahasiswa mendukung metode ini diterapkan di seluruh Universitas. Sedangkan dari sisi Ahli Materi, sebesar 100\% mengatakan bahwa perlu ada metode pengajaran baru. Dan ketika peneliti menanyakan apakah metode pembelajaran baru itu berupa game, maka kedua ahli materi tersebut juga seluruhnya, yaitu $100 \%$ mengatakan setuju, karena memberikan warna baru dalam dunia pengajaran. Namun untuk materinya sendiri masih kurang sesuai penyampaian dalam setiap misinya, maka perlu ditingkatkan pemahaman materi dengan misi yang harus diselesaikan pemain. Dari segi ahli media sendiri mengatakan bahwa sebesar $100 \%$ mengatakan bahwa game ini menarik untuk dimainkan begitu pun dilihat dari segi storyboard. Namun dari segi grafisnya seluruh ahli media, yaitu $100 \%$ mengatakan cukup menarik dan dari segi karakternya masih kurang dan monoton.

Sedangkan dari segi ketertarikan seluruh aspek koresponden mulai dari mahasiswa, ahli materi, dan ahli media terdapat rata-rata 3.67 (sangat baik) yang membuktikan bahwa game ini sudah membuat pemainnya tertarik untuk memainkan. Dari segi pemahamannya bernilai 4 (sangat baik) dimana dari hasil kuesioner juga membuktikan bahwa dengan memainkan game ini mereka tidak hanya mengingat kembali namun juga semakin paham dengan setiap materi yang diajarkan pada mata kuliah algoritma dan struktur data dan dari sisi kesesuaian materi dengan misinya memperoleh nilai 3.33 (baik), karena banyak yang berpendapat kurang penjelasan lebih dalam lagi terkait misinya.

\section{Metode Penelitian}

Menggunakan pendekatan penelitian pengembangan (research and development). Dalam hal ini yang dikembangkan adalah game pembelajaran. Metode penelitian dan pengembangan adalah metode penelitian yang digunakan untuk menghasilkan produk tertentu dan menguji keefektifan produk tersebut [8].

Banyak model pengembangan yang bisa digunakan, salah satunya adalah model pengembangan instruksional sistem. Pada Gambar 1, model ini dikembangkan oleh Molenda, Pershing, Reigeluth, et al. yang lebih dikenal dengan model ADDIE [9].

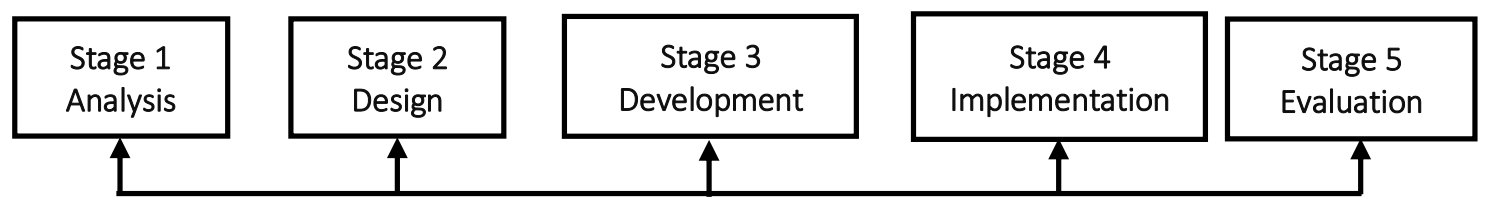

Gambar 1. Model Pengembangan ADDIE

Selain model pengembangan ADDIE [10] mengungkapkan tahapan dalam membangun dan mengembangkan multimedia seperti Gambar 2.

\subsection{Teknik Analisis Data}

Teknis analisis data yang dilakukan adalah menggunakan data kualitatif dan data kuantitatif. Data kualitatif dalam penelitian ini berupa kritik dan saran yang dikemukakan ahli media, ahli materi, dan pengguna. Data-data ini dikumpulkan untuk memperbaiki aplikasi game yang dibuat. Data kuantitatif berupa skor pada masing-masing item instrumen yang telah diisi oleh ahli media, ahli materi, dan pengguna. Data berupa saran revisi, komentar dan 
hasil pengamatan dianalisis secara deskriptif kualitatif. Data yang diperoleh dijadikan masukan untuk melalukan revisi terhadap media yang dikembangkan. Data angket berupa skor dikonversikan menjadi nilai dengan skala 5. Skor yang telah diubah dengan skala likert kemudian diberi rerata.

\section{Hasil Penelitian dan Pembahasan}

Pada bab hasil dan penelitian dijelaskan hasil dari penelitian dan pembahasan yang lengkap. Hasil dapat direpresentasikan dalam gambar, grafik, tabel dan lainnya yang dapat mempermudah pembaca dalam memahami makalah. Penjelasan dapat dibuat dalam bentuk sub bab.

\subsection{Tahap Analisis}

Tahap analisis adalah suatu tahap pengumpulan informasi yang dapat dijadikan sebagai bahan untuk membuat produk, dalam hal ini produk yang dihasilkan adalah media pembelajaran game. Pengumpulan informasi berupa pembuatan kuesioner, analisis kebutuhan, analisis perangkat keras dan perangkat lunak yang dibutuhkan untuk membuat produk. Tahap analisis dibagi menjadi empat tahapan, yaitu analis kuesioner, analisis kebutuhan, analisis perangkat keras dan analisis perangkat lunak. Dimana analisis awal telah dilakukan sebelum menciptakan game untuk penelitian ini. Didapat presentasi tingkat pemahaman mahasiswa Teknik Informatika Universitas Muhammadiyah Sidoarjo 14.3\% dan tingkat kesukaan mereka hanya $8.2 \%$, seperti terlihat pada Gambar 3 .

Multimedia Instructuional Design Process

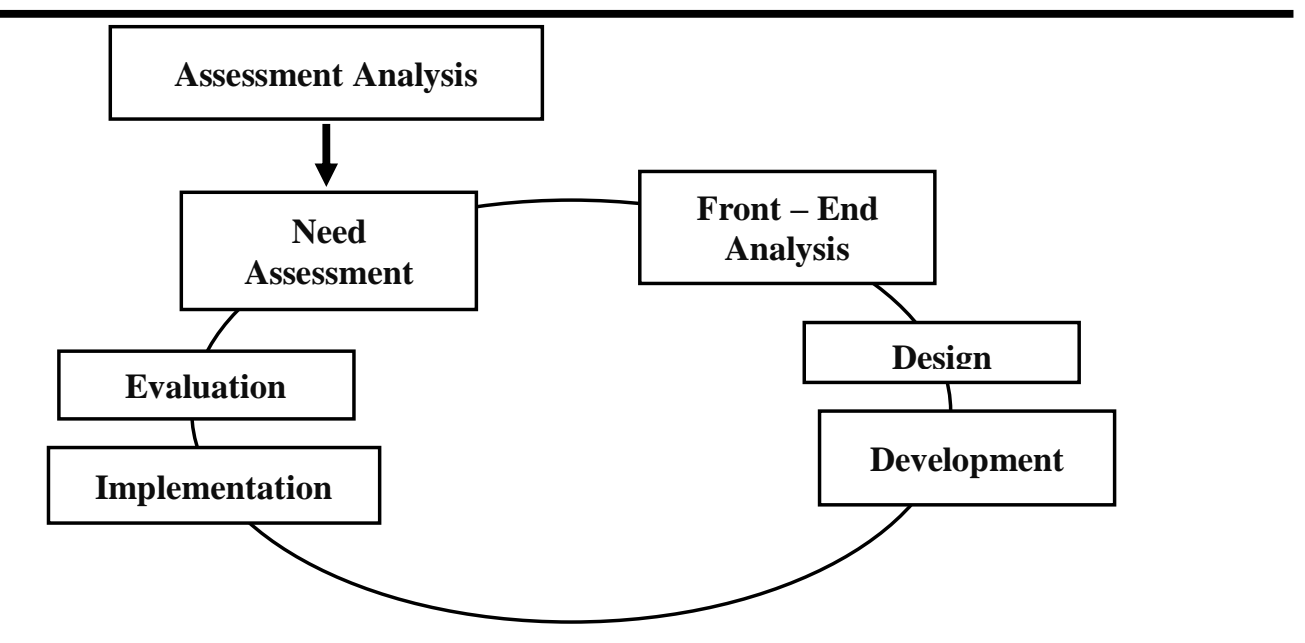

Gambar 2. Multimedia Instructional Design Proces

\section{Pilih Pemrograman apa saja yang SUDAH Anda PAHAMI (70 tanggapan)}

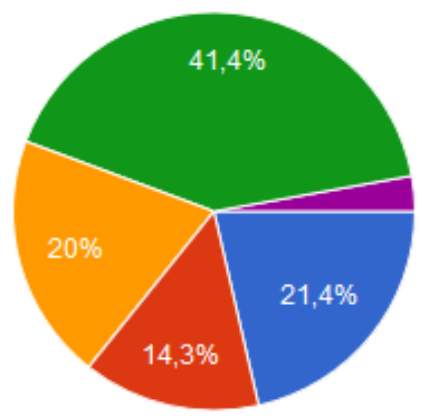

Algortima Pemrograman

Algoritma Struktur Data

Pemrograman Berbasis Objek

Pemrograman Berbasis Web

Lainnya

Gambar 3. Hasil Kuisioner Mata Kuliah yang Kurang Dipahami 


\subsection{Desain}

Tahap desain dilakukan untuk mempermudah peneliti dalam merancang aplikasi game yang akan dibangun. Tahap desain meliputi flowchart, FSM dan storyboard. Gambar 4 memperlihatkan flowchart game algoritma dan struktur data "Fun with ALGOS".

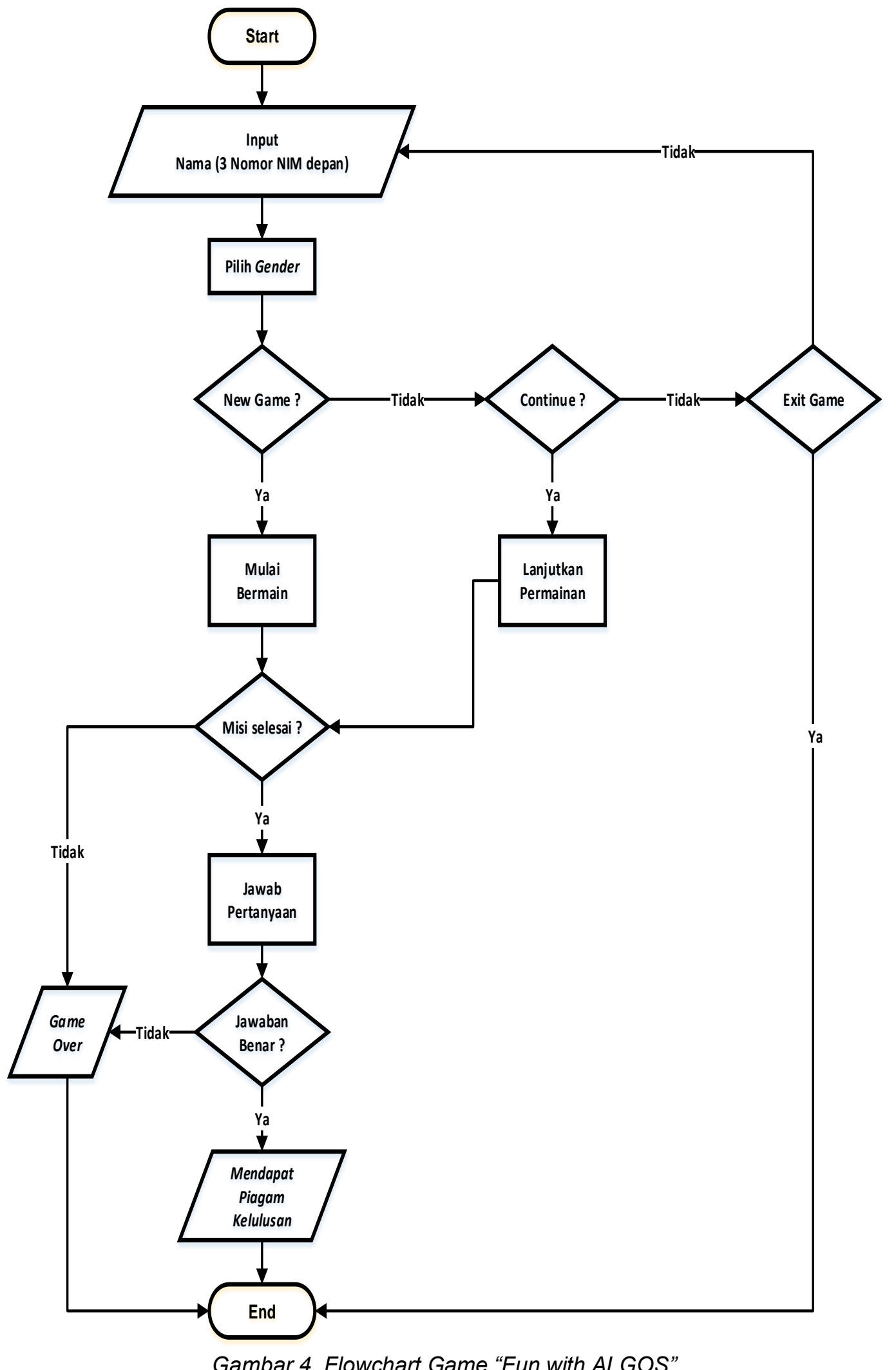

Rancang Bangun Game Algoritma dan Struktur Data Berbasis Role Game Playing.., Cindy Taurusta, Yulian Findawati 
Dalam game ini juga terdapat FSM (finite state machine) yang akan ditunjukkan oleh Gambar 5 dan Gambar 6.

\subsubsection{Main}

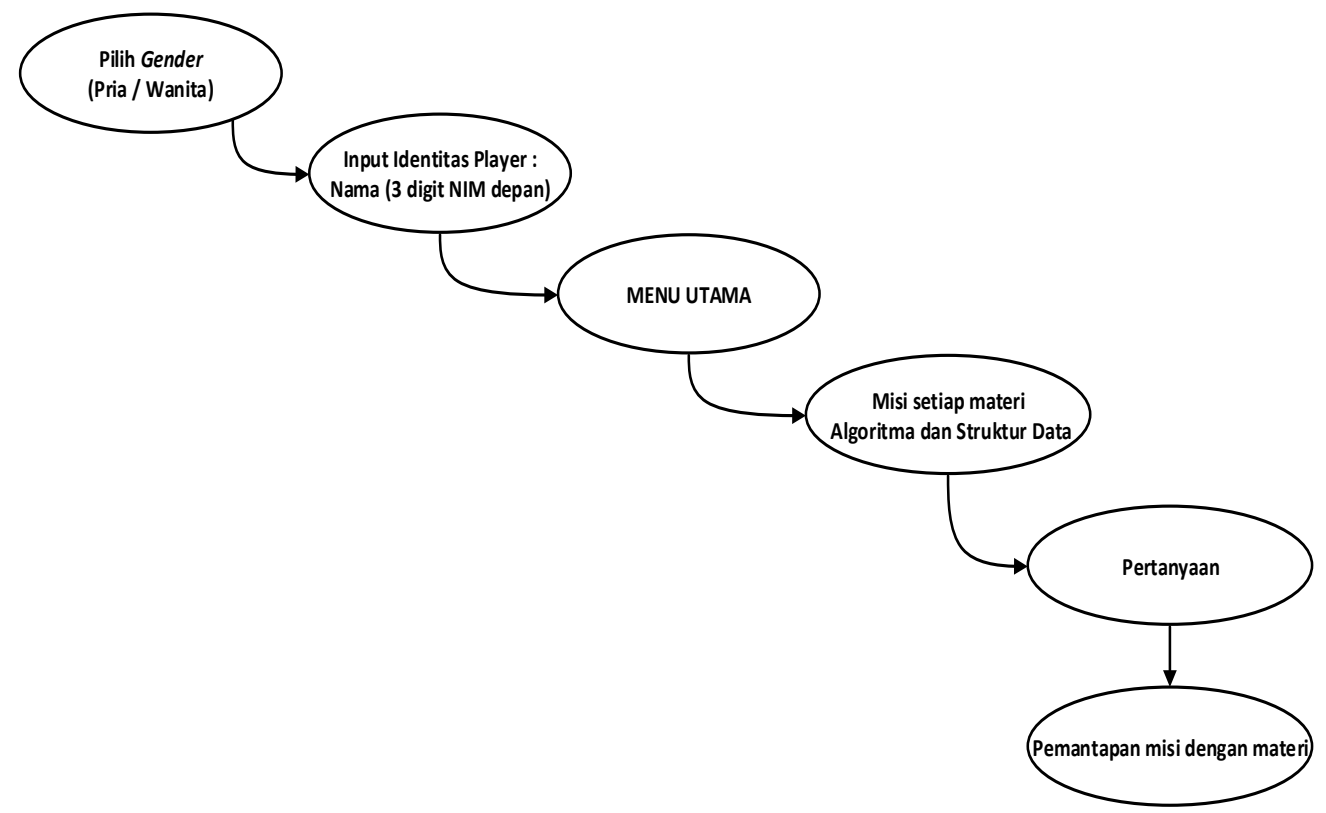

Gambar 5. Finite State Machine Scene Main

\subsubsection{Penyelesaian Misi}

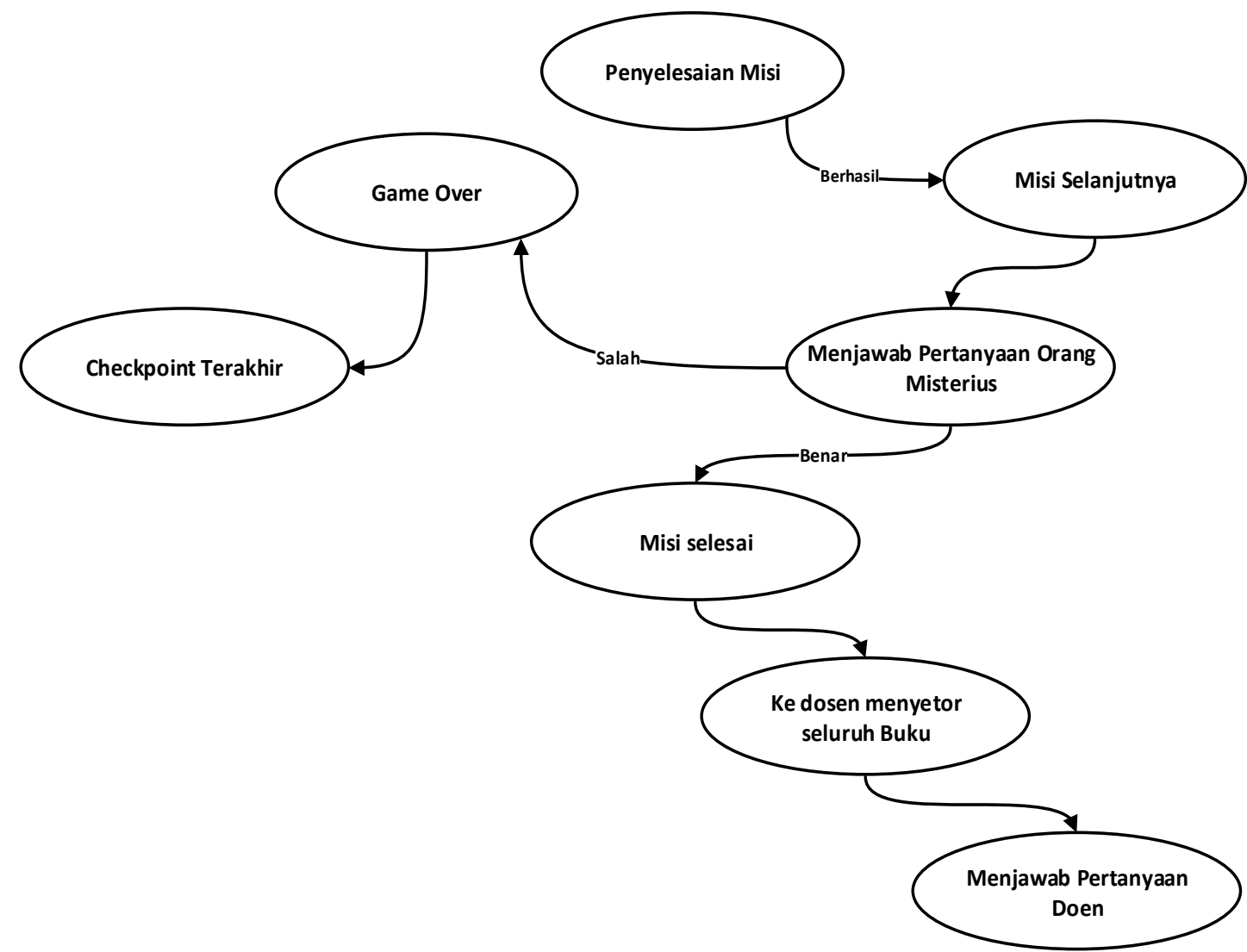

Gambar 6. Finite State Machine Penyelesaian Misi

KINETIK Vol. 2, No. 3, Agustus 2017: 175-188 


\subsubsection{Pembuatan Game}

Pembuatan game ini mulai dari interface awal seperti Gambar 7, misi setiap materi dalam mata kuliah algoritma dan struktur data, dan pertanyaan-pertanyaan test dari Dosen dan orang misterius demi meningkatkan pemahaman mahasiswa atau pemain.

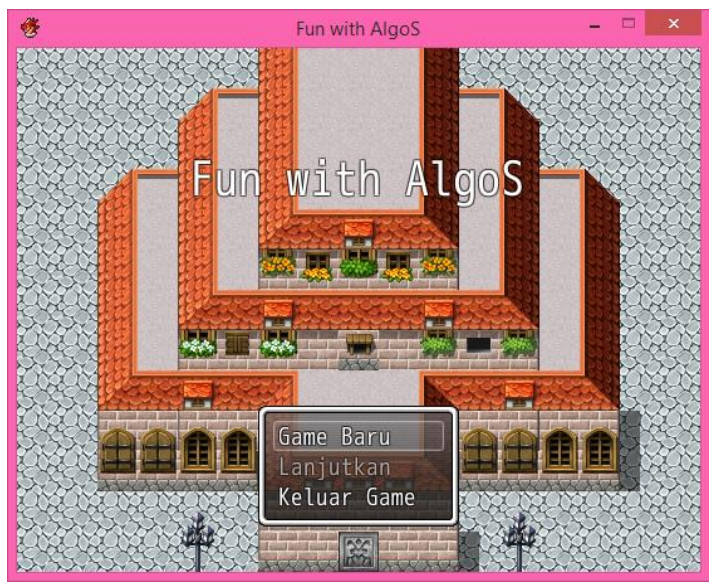

Gambar 7. Interface Awal Game

Misi awal dari Dosen (Gambar 8) agar mendapatkan pembelajaran di setiap materi sambil menyelesaikan misi setiap materi tersebut:

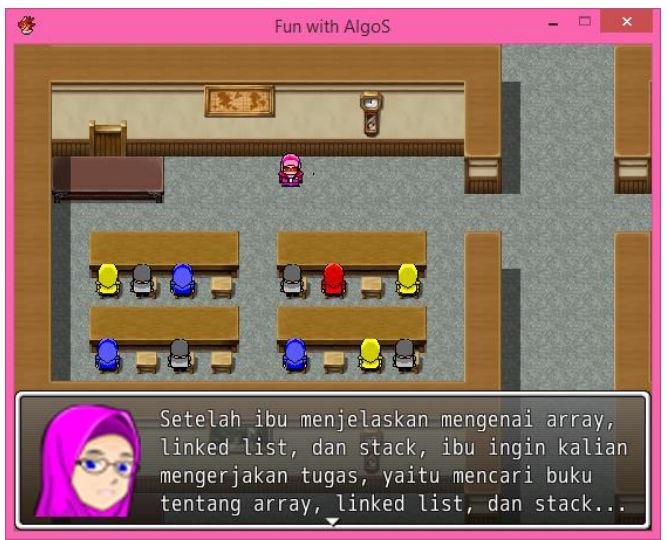

Gambar 8. Isi Misi Awal Dari Dosen

Misi materi array (Gambar 9), yaitu mencari lima teman dan mendudukkannya ke kursi di Gudang Bawah Tanah secara urut berdasarkan kode ALGOS.

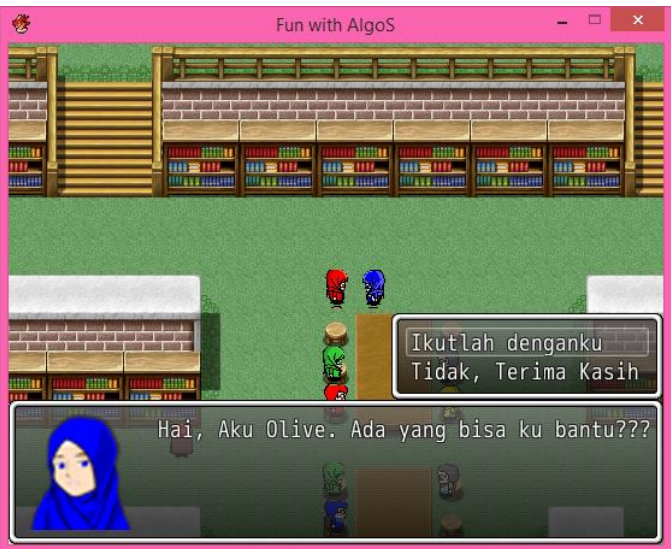

(a)

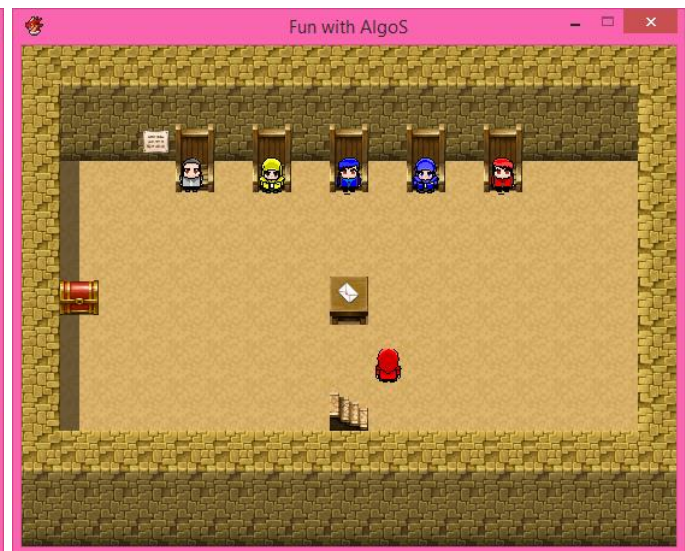

(b)

Gambar 9. Misi Materi Array (a) Mencari 5 Teman (b) Mendudukan Urut Kode ALGOS

Rancang Bangun Game Algoritma dan Struktur Data Berbasis Role Game Playing.., Cindy Taurusta, Yulian Findawati 
Pertanyaan di setiap misi selain membantu mempertajam ingatan pemain, namun juga sebagai pengukur tingkat pemahaman pemain dengan materi yang disampaikan secara tersembunyi melalui misinya, berikut pertanyaan untuk materi array (Gambar 10).

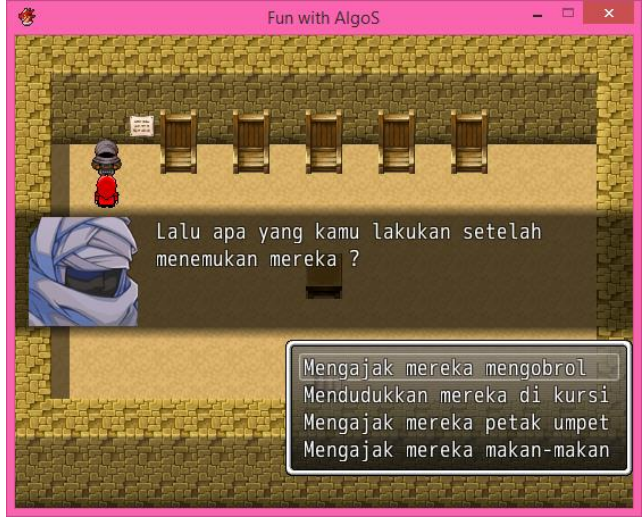

(a)

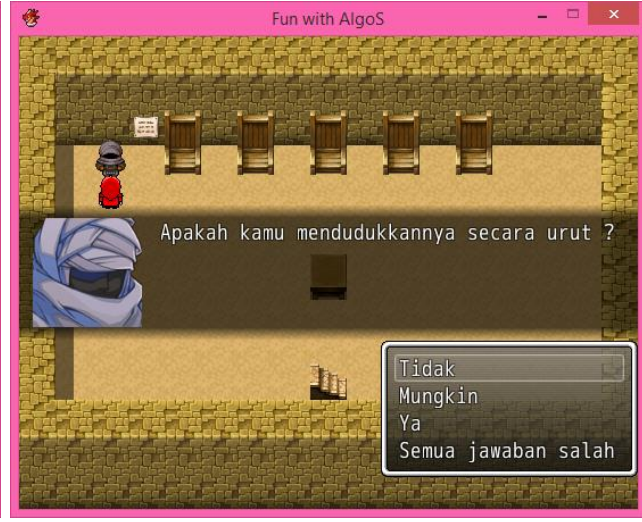

(b)

Gambar 10. (a) (b) Pertanyaan Setelah Menyelesaikan Misi Array

Misi materi (Gambar 10) linked list, yaitu mencari lima teman dan mendudukkannya ke kursi di gudang bawah tanah tidak urut dan berdasar keinginan teman-temannya tersebut (Gambar 11).

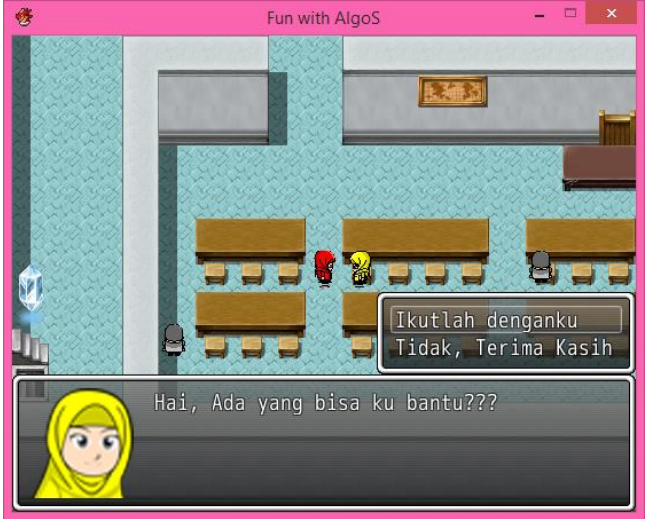

(a)

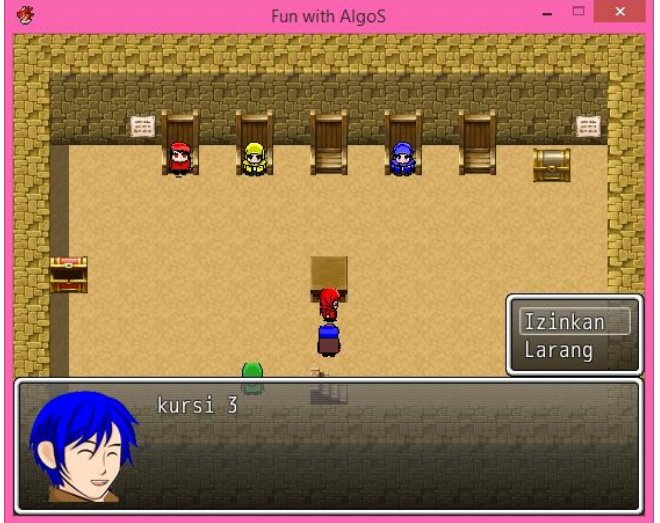

(b)

Gambar 11. (a) Mencari teman (b) Mengizinkan Teman yang Memilih Posisi Kursi

Setiap pemain yang berhasil menyelesaikan misi, pasti bertemu dengan orang misterius yang akan memberikan beberapa pertanyaan seputar misinya tersebut (Gambar 12).

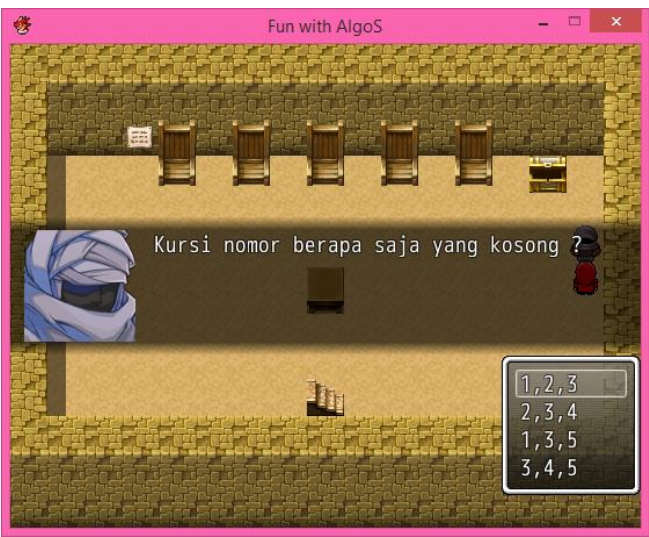

(a)

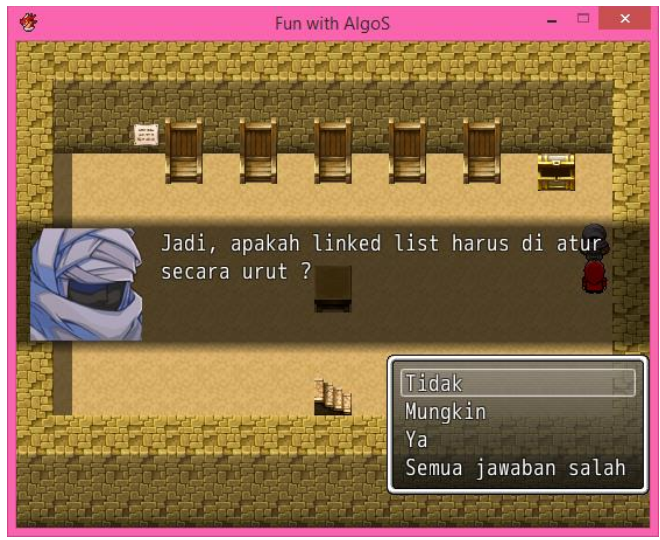

(b)

Gambar 12. (a) (b) Pertanyaan Setelah Menyelesaikan Misi Linked List

KINETIK Vol. 2, No. 3, Agustus 2017: 175-188 
Misi materi linked list, yaitu mencari ketiga teman yang telah meminjam buku di perpustakaan lalu mengembalikan berdasar urutan jadwal pengembaliannya (Gambar 13).

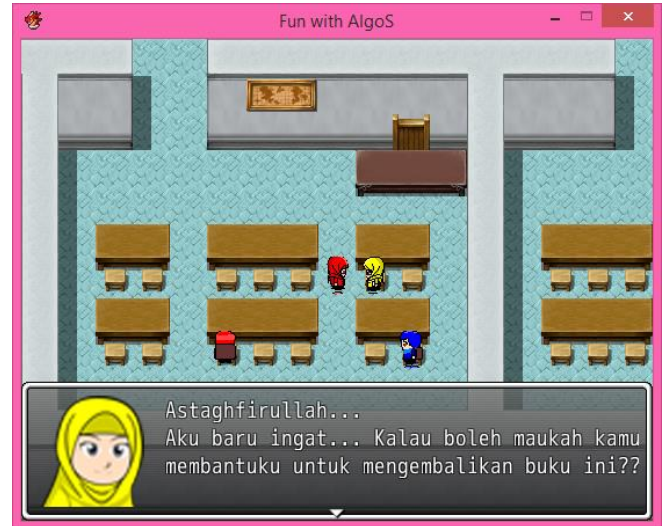

(a)

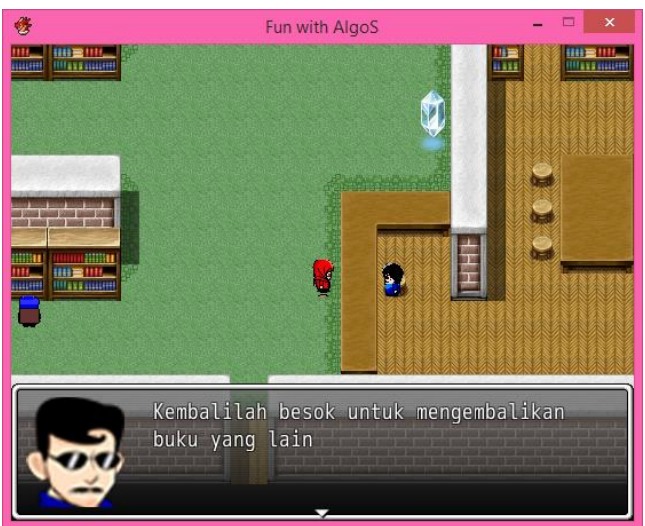

(b)

Gambar 13. (a) Mencari Peminjam Buku (b) Mengembalikan ke Petugas Perpustakaan

Pertanyaan yang terdapat dalam materi stack (Gambar 13).

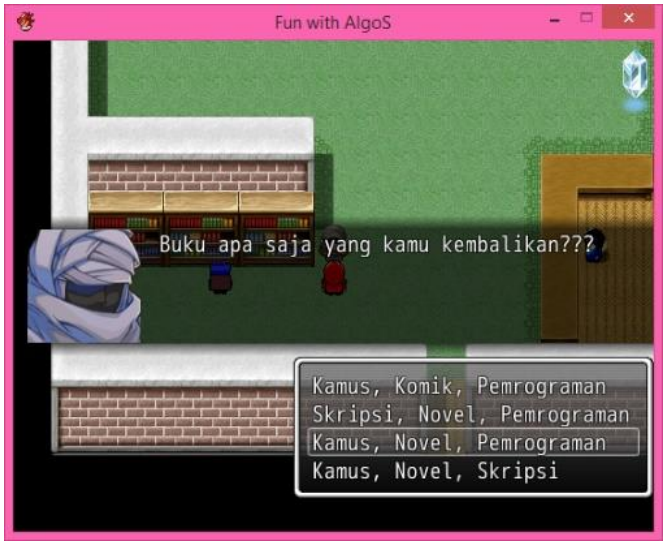

(a)

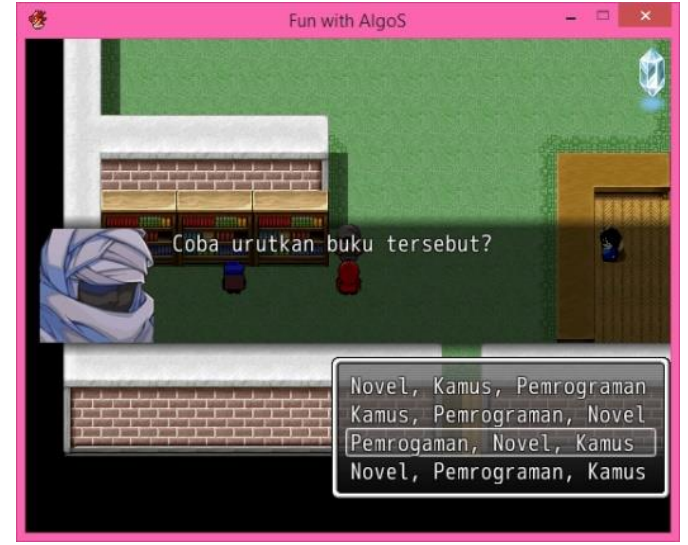

(b)

Gambar 14. (a) (b) Pertanyaan Setelah Menyelesaikan Misi Stack

Game ini memiliki 13 level dan level ini menunjukkan tahapan yang berhasil dilalui. Level ini berguna saat pengujian, dimana pemain satu dengan pemain lainnya pada waktu tertentu dapat dibandingkan tingkat kemampuannya dalam menyelesaikan misi-misi yang terdapat dalam game algoritma dan struktur data seperti pada Gambar 15.

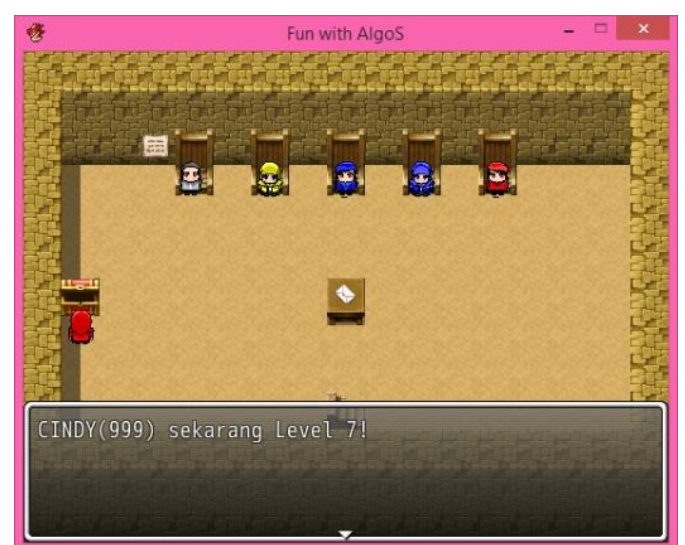

(a)

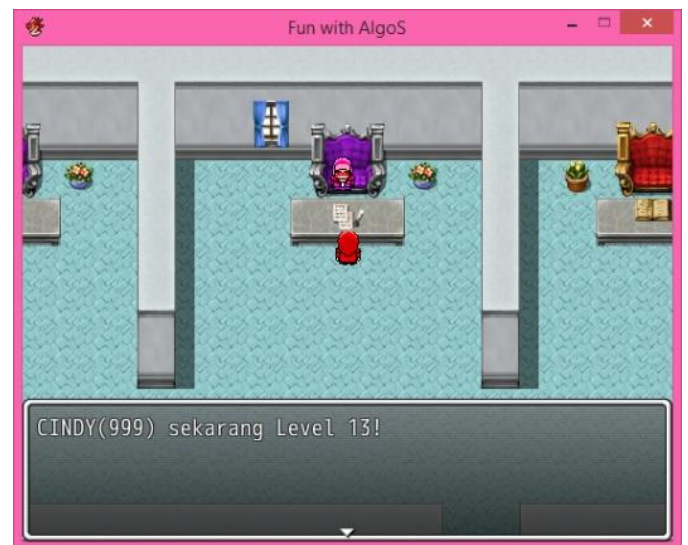

(b)

Gambar 15. (a) (b) Beberapa Level Pemain

Rancang Bangun Game Algoritma dan Struktur Data Berbasis Role Game Playing.., Cindy Taurusta, Yulian Findawati 
Dalam game RPG (role playing game) memiliki jalan cerita yang panjang dan misi yang banyak, maka pemain harus rajin menyimpan progres yang ia lakukan. Dalam RPG Maker VX Ace terdapat 16 ruang untuk penyimpanan. Penyimpanan berfungsi sebagai check point akhir bila pemain melakukan kesalahan sehingga game over. Maka dengan menyimpan di file 9 (misal), yaitu saat telah menemukan 2 buku, maka apabila pemain game over, dia tetap bisa melanjutkan permainan dan itu berada di keadaan terakhir ia telah menemukan 2 buku pada Gambar 16.

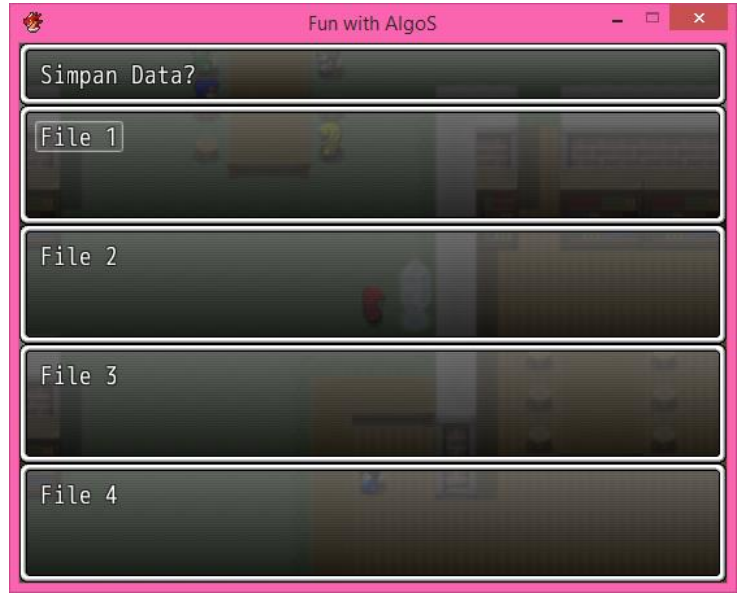

(a)

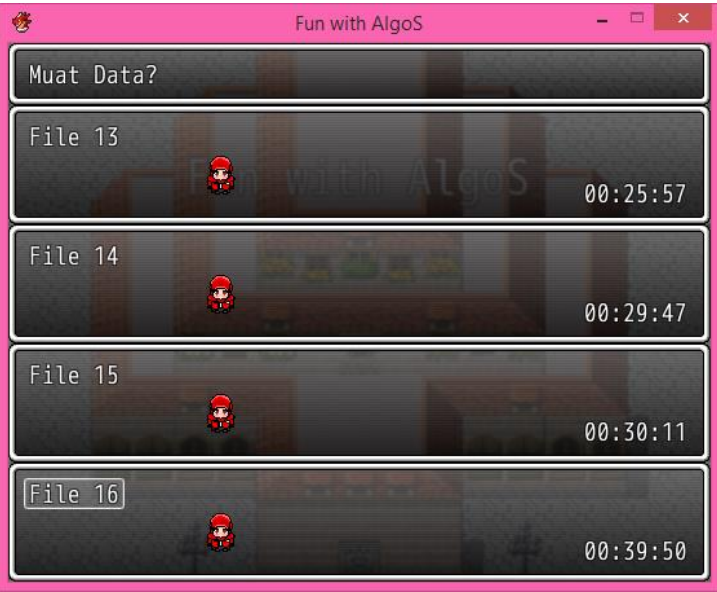

(b)

Gambar 16. (a) Ruang Penyimpanan Kosong (b) Ruang Penyimpanan Penuh

\subsubsection{Teknik Analisa Data}

Gambar 17 dan Gambar 18 menunjukkan beberapa hasil analisa kuesioner yang telah dibagikan peneliti kepada mahasiswa, ahli materi, dan ahli media.

1. Mahasiswa

7. Lebih suka diterangkan dan diberi tugas, diberi studi kasus untuk didiskusikan dan dipresentasikan, atau bermain game sambil mengungkap misi yang terdapat pembelajaran materi? (21 tanggapan)

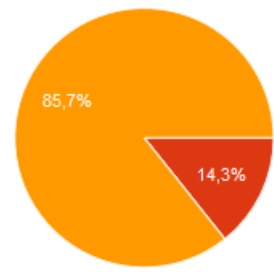

Diterangkan dan diberi tugas

Diberi studi Kasus untuk didiskusikan dan dipresentasikan

Bermain game sambil mengungka misi yang terdapat pembelajaran materi

Gambar 17. Tingkat Kesukaan Mahasiswa di Algoritma dan Struktur Data

9. Apakah game ini sudah cukup efektif untuk pembelajaran mata kuliah Algoritma dan Struktur Data?

(21 tanggapan)

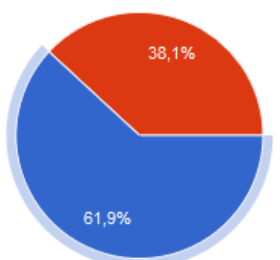

Sudah, sangat efektif, bagus, da enyenangkan

Kurang, perlu pendalaman di setiap

materi dan misiny

Tidak, sama sekali tidak membantu

dalam pembelajaran

Gambar 18. Tingkat Keefektifan Game Sebagai Media Pembelajaran

KINETIK Vol. 2, No. 3, Agustus 2017: 175-188 
Ahli materi, yaitu tentang game ini apakah dapat menjadi penambahan metode pembelajaran, dapat terlihat di Gambar 19.

Apakah menurut Anda perlu tambahan metode pengajaran ? (2 tanggapan)

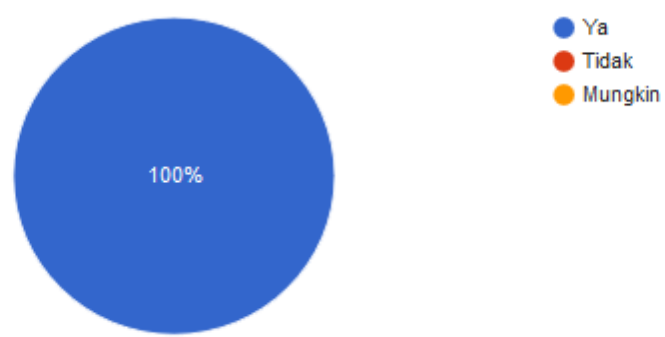

Gambar 19. Hasil Kuesioner Tentang Penambahan Metode Pengajaran

Gambar 20 menunjukkan bahwa ahli materi menyetujui bahwa game dapat digunakan sebagai metode pembelajaran.

Jika ada, setujukan dengan menggunakan GAME sebagai media pembelajaran?

(2 tanggapan)

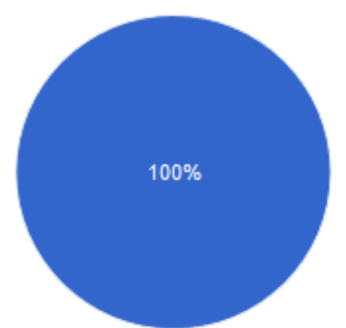

Setuju, memberi warna baru dalam pengajaran

Kurang setuju, karna tidak semua suka bermain game

Tidak setuju, kurang efektif dan membuang - buang waktu

Gambar 20. Hasil Kuesioner Tentang Game Sebagai Media Pembelajaran Baru

Kemudian Gambar 21 menunjukkan bahwa ahli materi menilai bahwa materi dengan misi dalam game sudah sesuai.

Setelah Anda bermain game ini, sesuaikan materi yang diajarkan dengan misi dalam game ini?

(2 tanggapan)

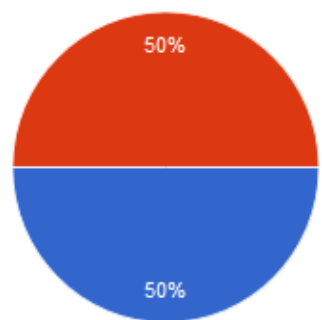

Ya, sangat sesuai dan menyenangkan

Kurang, masih tidak membuat pemain

mendalami materinya

Tidak sesuai, jauh dari materi yang

seharusnya

Gambar 21. Hasil Kuesioner Tentang Kesesuaian Materi Dengan Misi Dalam Game

Ahli media tentang tingkat kemenarikan game dari segi grafis dan karakter di dalamnya, dapat dilihat di Gambar 22 dan Gambar 23. 
Bagaimana segi grafisnya? (2 tanggapan)

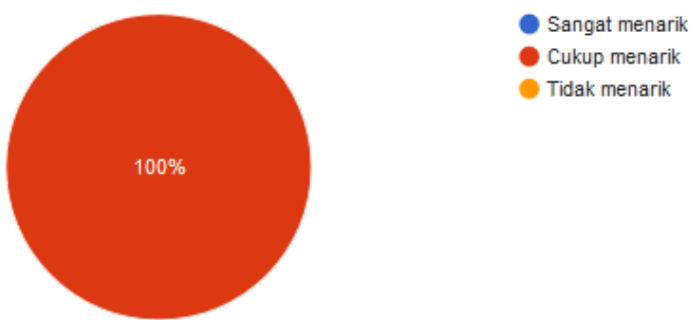

Gambar 22. Hasil Kuesioner Kemenarikan Segi Grafis Game

Bagaimana segi karakter di dalamnya ? (2 tanggapan)

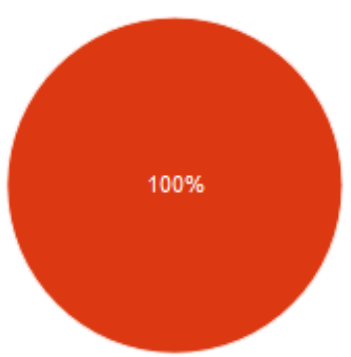

Bagus, sesuai dengan temanya

Kurang, masih sedikit dan monoton

Jelek, tidak sesuai dengan tema

Gambar 23. Hasil Kuesioner Tentang Karakter Game "Fun with ALGOS"

Sedangkan hasil kuesioner untuk Ahli Media tentang game ini segi jalan cerita (storyboard) dan cara bermain (gameplay), dapat terlihat di Gambar 24 dan Gambar 25.

Bagaimana segi storyboardnya ? (2tanggapan)

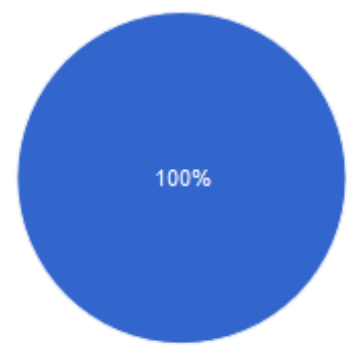

Menarik, runtut sesuai isi gamenya

Cukup, masih kurang jelas isi

gamenya

Jelek, tidak ada harmonisasi dalam isi

gamenya

Gambar 24. Hasil Kuesioner Segi Storyboard Game

Bagaimana segi gameplaynya ? (2 tanggapan)

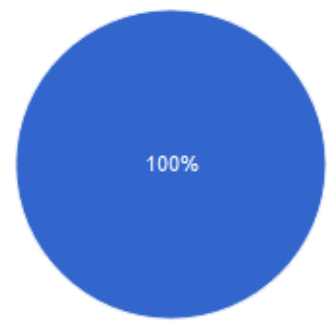

Menyenangkan, menarik, membuat penasaran

Biasa saja, umum seperti game

edukasi lain

Jelek, monoton, membosankan

Gambar 25. Hasil Kuesioner Segi Gameplay

KINETIK Vol. 2, No. 3, Agustus 2017: 175-188 


\section{Kesimpulan}

Dari hasil kuesioner yang dibagikan peneliti kepada para mahasiswa baik mahasiswa aktif maupun alumni, didapatkan mayoritas mahasiswa lebih suka bermain game sambil mengungkapkan misi, yaitu sebesar $85,7 \%$. Dan didapat bahwa sebesar $61,9 \%$ koresponden mengatakan bahwa game algoritma dan struktur data "Fun with ALGOS" ini sudah dapat dikatakan sangat efektif, bagus, dan menyenangkan. Sedangkan hasil apakah game ini perlu diterapkan dalam metode pengajaran algoritma dan struktur data, didapat sebesar 66,7\% mahasiswa mendukung metode ini diterapkan di seluruh Universitas. Sedangkan dari sisi Ahli Materi, sebesar $100 \%$ mengatakan bahwa perlu ada metode pengajaran baru. Dan ketika peneliti menanyakan apakah metode pembelajaran baru itu berupa game, maka kedua ahli materi tersebut juga seluruhnya yaitu 100\% mengatakan setuju, karena memberikan warna baru dalam dunia pengajaran. Namun, untuk materinya sendiri masih kurang sesuai penyampaian dalam setiap misinya, maka perlu ditingkatkan pemahaman materi dengan misi yang harus diselesaikan pemain. Dari segi ahli media sendiri mengatakan bahwa sebesar 100\% mengatakan bahwa game ini menarik untuk dimainkan begitu pun dari segi storyboard.

Namun dari segi grafisnya seluruh ahli media yaitu $100 \%$ mengatakan cukup menarik dan dari segi karakternya masih kurang dan monoton. Sedangkan dari segi ketertarikan seluruh aspek koresponden mulai dari mahasiswa, ahli materi, dan ahli media terdapat rata-rata 3.67 (sangat baik) yang membuktikan bahwa game ini sudah membuat pemainnya tertarik untuk memainkan. Dari segi pemahamannya bernilai 4 (sangat baik) dimana dari hasil kuesioner juga membuktikan bahwa dengan memainkan game ini mereka tidak hanya mengingat kembali namun juga semakin paham dengan setiap materi yang diajarkan pada mata kuliah algoritma dan struktur data. Dan dari segi Kesesuaian materi dengan misinya memperoleh nilai 3.33 (baik) karena banyak yang berpendapat kurang penjelasan lebih dalam lagi terkait misinya.

\section{Referensi}

[1] N. Alfiah, "Digitalisasi Koleksi Audio Dengan Aplikasi Software Magix Audio Cleaning Lab Dalam Pustaka Pandang Dengar (Audio Visual) Di Perpustakaan Institut Seni Indonesia Surakarta."

[2] I. Santyasa, "Pendidikan, Pembelajaran, dan Penilaian Berbasis Kompetensi Makalah," Seminar Jurusan Pendidikan Fisika IKIP Negeri Singaraja, 2003.

[3] Sutarman, Pengantar Teknologi Informasi. Jakarta: PT Bumi Aksara, 2009.

[4] M. J. Hannafin and K. L. Peck, The design, Development, and Evaluation of Instructional Software. McMillan Publishing Company, 1988.

[5] I. Widiastuti, "Pemilihan Perilaku NPC Pada Game Pertarungan Jarak Dekat Menggunakan Fuzzy Coordinator," 2012.

[6] S. . Supeno Mardi, Y. M. Arif, M. Hariadi, and M. H.P, "Perilaku Taktis Untuk Non-Player Characters di Game Peperangan Meniru Strategi Manusia Menggunakan Fuzzy Logic dan Hierarchical Finite State Machine,” Jurnal IImiah Kursor, Vol. 6, No. 1, 2011.

[7] D. Clark, "Game and E-Learning, Sunderland: Caspian Learning," www.caspianlearning.co.uk, 2006. [Accessed: 20-May-2009].

[8] Sugiyono, Metode Penelitian Pendidikan Pendekatan Kuantitatif, Kualitatif, dan R\&D. Bandung: Alfabeta, 2009.

[9] L. Dick, W., Carey and J. O. Carey, The Systematic Design of Instruction (5th ed). New York: Longman, 2001.

[10] W. Lee and D. Owens, Multimedia-based Instructional Design: Computer-Based Training, Web-Based Training, Distance Broadcast Training, Performance-Based Solutions. John Wiley \& Sons, 2004. 
